\title{
Agrobacterium-Mediated Transformation of Cry8db Gene in Vietnam Sweet Potato Cultivar
}

\author{
Pham Bich Ngoc ${ }^{1}$, Vu Thi Lan ${ }^{1,2}$, Tran Thu Trang ${ }^{1}$, Nguyen Hoai Thuong ${ }^{1}$, Le Thu Ngoc ${ }^{1}$, Chu Hoang Ha ${ }^{1}$ and \\ Le Tran Binh ${ }^{1,3}$ \\ 1. Institute of Biotechnology, Vietnam Academy of Science and Technology, 18-Hoang Quoc Viet, Cau Giay, Ha Noi 10000, Vietnam \\ 2. College of Science, Thai Nguyen University, Tan Thinh, Thai Nguyen 23000, Vietnam \\ 3. University of Science and Technology of Ha Noi, 18-Hoang Quoc Viet, Cau Giay, Ha Noi 10000, Vietnam
}

Received: May 29, 2015 / Accepted: June 22, 2015 / Published: June 30, 2015.

\begin{abstract}
Sweet potato [Ipomoea batatas (L.) Lam.] is an important food crop in the world as well as in Vietnam. It is well known as a recalcitrant crop for gene transformation and tissue culture because of its genotype dependent in vitro responses. In present study, Agrobacterium-mediated transformation of cry $8 D b$ from Bacillus thuringiensis into KB1 sweet potato variety has been studied. The $\mathrm{C} 58 \mathrm{cv}$ strain carrying a pBI121 backbone which contained $c r y 8 D b$ delta-endotoxin gene regulated under $35 \mathrm{~S}$ CaMV promoter, and the selection marker gene, neomycin phosphotransferase (nptII) gene, was subjected for plant transformation. Callus induced from shoot tips and leaf explants were inoculated and cocultured with A. tumefaciens. The selection occurred during callus producing and plant regenerating steps. A total of 201 transgenic putative plant lines were produced, and 21 transgenic lines were positively confirmed by PCR and finalized by Southern blot. Four putative transgenic lines confirming a single copy of the cry $8 D b$ gene were transferred into soil pots in greenhouse. Biological activity evaluation for the insecticidal capacity of these transgenic lines under controlled conditions showed that the level of infestation by sweet potato weevils (Cylas formicarius) in untransformed plants was higher than that of transgenic lines.
\end{abstract}

Key words: Sweet potato, Agrobacterium tumefaciens, plant transformation, cry $8 D b$, sweet potato weevil resistance, cylas formicarius.

\section{Introduction}

Ipomoea batatas (L.) Lam. (Convolvulaceae, Dicotyledons) produces storage roots rich in carbohydrates and $\beta$-carotene, a precursor of vitamin $\mathrm{A}$, and its leaves are rich in proteins. The roots also contain vitamins $\mathrm{C}$, vitamin $\mathrm{B}$ complex, and vitamin $\mathrm{E}$ as well as potassium, calcium, and iron [1]. In Vietnam, sweet potato ranks fourth in the top list of important crops after rice, corn and cassava. According to the world crop statistics, the production of sweet potato in Vietnam ranks sixth, after China, Nigeria, Uganda, Indonesia, and Tanzania with an annual production around $1.367 \mathrm{Mt}$. However, the

Corresponding author: Le Tran Binh, Ph.D., Professor, research field: plant biotechnology. E-mail: le-tran.binh@usth.edu.vn. average yield of sweet potato in Vietnam ( 9 tons per ha) is extremely lower than that in Japan (23 tons per ha) and China (21 tons per ha). Increasing the production of sweet potato is limited by the severe damage caused by pests and diseases [2].

Improvement of sweet potato production through conventional breeding is a complicated process and has not been very successful. This is due to the fact that sweet potato is a hexaploid crop and genes from the cultivated sweet potato gene pool are not easily accessible by direct sexual hybridization. A highly promising alternative to the conventional breeding is the introduction of foreign genes into plants through genetic transformation. Attempts over the last few years to produce transformed sweet potato plants utilized different gene transfer systems such as 
transformation by electroporation [3-5], particle gun bombardment [6-11] or A. rhizogenes [12]. Since the Agrobacterium mediated transformation system does not involve sophisticated equipment and frequently produces cleaner events (intact integrations and single copy) than other methods [13], it remains to be the more favorable approach. Previous studies on sweet potato transformation via Agrobacterium tumefaciens transformation have been reported including herbicide resistance [14, 15], viral resistance [16], insect resistances related to the CryIIIA delta-endotoxin, cowpea trypsin inhibitor and snowdrop lectin $[17,18]$ and enhancing starch accumulation in tubers $[19,20]$. To date, effective transformation protocols have been developed for only few of sweet potato cultivars, indicating that it is a very recalcitrant species and transformation methods of sweet potato are still genotype dependent.

In Vietnam, as almost worldwide, sweet potato is the most susceptible to $C$. formicarius. More than $50 \%$ of sweet potato crops are lost due to this pest. The expression of insecticide genes into sweet potato plants to control pest resistance is an appropriate alternative to reduce crop loss. Recently, the activities of some insecticidal genes from Bacillus to control coleopteran species have been well characterized. Bt galleriae SDS-502 [21] and Bt BT185 [22] were isolated as strains possessing toxicity to larvae of the scarab beetles. Two cry genes, $\mathrm{cry} 8 \mathrm{Ca}$ from Buibui and cry $8 D a$ from SDS-502 were cloned, and their protein showed toxicity against certain scarab beetle species [21, 23]. Another novel cry gene, cry8Db, highly toxic to scarab beetles such as the Japanese beetle, was cloned from an isolate of Bacillus thuringiensis (Bt), BBT2-5. The cry $8 D b$ gene has the length of $3525 \mathrm{bp}$ and codes for a protein of 1,174 amino acid residues. Studies also showed that the deletions of domain 3 (517-686) of cry $8 D$ appeared to be not involved in the insect host specificity. The activity against insects is determined by Domain 2 (290-516) [24].
The objective of present study was to generate transgenic sweet potatoes resistant to sweet potato weevil. Particularly, the study is designed to 1) optimize codon usage of an active $c r y 8 D b$ gene region for expression in a plant; 2) construct transformation vector carrying the synthesis $c r y 8 D b$ gene; 3) transform $c r y 8 D b$ into sweet potato via Agrobaterium tumefaciens; and 4) analyze the transformants and biological tests.

\section{Materials and Methods}

\subsection{Plant Materials and Culture Conditions}

KB1 sweet potato variety (Ipomoea batatas [L.] Lam.) used in the experiments was kindly provided by Root Crop Research and Development Center, Vietnam Academy of Agricultural Sciences.

$\mathrm{CP}$ and EP basal medium [25] was used in the experiment. The $\mathrm{pH}$ of all media was adjusted to 5.8 before autoclaving at $118^{\circ} \mathrm{C}$ for $20 \mathrm{~min}$.

To establish in vitro cultures, shoots with the length of $10 \mathrm{~cm}$ were excised from greenhouse-grown plants and were rinsed under running tap water for $15 \mathrm{~min}$. Then, the shoot tips were cut to $3 \mathrm{~cm}$ in length. The shoots were sterilized by briefly immersing in $70 \%$ $(\mathrm{v} / \mathrm{v})$ ethanol for $20 \mathrm{~s}$, rinsing with sterile, distilled water, immersing into $0.1 \%$ mercuric chloride solution for $3 \mathrm{~min}$, and then rinsing three more times with sterile, distilled water. The surface-sterilized shoot tips were blotted dry on sterile filter paper. All of the explants were cultured on the MS basal medium for propagation.

A two-stage protocol for plant regeneration was followed $\mathrm{Vu}$ Thi Lan et al. [26, 27]. The stage 1 culture consisted of basal medium supplemented with $0.5 \mathrm{mg} / \mathrm{L}$ picloram and $2,237 \mathrm{mg} / \mathrm{L} \mathrm{KCl}$ for callus production (CP medium) for 3-4 weeks. In the stage 2, the EP basal medium was supplemented with 1.0 $\mathrm{mg} / \mathrm{L} \mathrm{ABA}$ and $1.0 \mathrm{mg} / \mathrm{L} \mathrm{GA} 3$ for for 2 weeks (IRM). Shoots were regenerated from callus in MS medium containing $0.5 \mathrm{mg} / \mathrm{L}$ kinetin and $1.0 \mathrm{mg} / \mathrm{L}$ BAP [18]. Shoots $2-3 \mathrm{~cm}$ in length were rooted on MS medium. 


\subsection{Agrobacterium and the Binary Vector}

The roughly $2.1 \mathrm{~kb}$ of $c r y 8 D b$ gene (AB303980) was optimized codon usage for expression in plants and synthesized artificially. For easier purification and immunological detection, $c r y 8 D b$ gene was fused to a poly-histidine tag and a cMyc-tag at the $\mathrm{C}$ terminus. In order to clone $c r y 8 D b$ into pBI121 under the control of CaMV promoter, the nucleotide sequences of BamHI and SmaI recognition sites were added into the N-terminal and C-terminal of $c r y 8 D b$ gene, respectively. The generating binary vector pBI121/Cry $8 D b$ was transformed into A. tumefaciens strain $\mathrm{C} 58 \mathrm{cv}$. The nptII gene was designed for the selection of kanamycin resistance (Fig. 1)

Cry $8 D b$ is transcriptionally controlled by the P35S promoter and $\mathrm{T} 35 \mathrm{~S}$ terminator. In addition cry $8 \mathrm{Db}$ gene was fused to a poly-histidine tag and a cmyc-tag at the $\mathrm{C}$ terminus. The nptII gene was designed for the selection of kanamycin resistance in plant.

\subsection{Genetic Transformation}

A colony of $A$. tumefaciens strain $\mathrm{C} 58 \mathrm{cv}$ carrying a binary vector pBI121 containing $c r y 8 D b$ gene was cultured on $50 \mathrm{~mL} \mathrm{LB}$ medium at $28{ }^{\circ} \mathrm{C}, 200 \mathrm{rpm}$ on an orbital shaker for 14-16 h. Then, the bacterial cells were collected by centrifugation at $5,000 \mathrm{rpm}$ for 10 min and resuspended in $25 \mathrm{~mL} \mathrm{1/2} \mathrm{MS} \mathrm{medium} \mathrm{[28].}$

Shoot tips and leaf explants were cut in 0.3-0.4 cm in $1 / 2$ MS liquid medium and placed on $\mathrm{CP}$ for induction. After three days, explants were transferred onto a new plate containing $25 \mathrm{~mL}$ of agrobacterial suspension and incubated for $30 \mathrm{~min}$ with gentle shaking. The bacteria were discarded and the explants were dried on sterile filter paper and placed on $\mathrm{CP}$ solid medium under low light intensity. After three days inoculated with bacteria, the explants were placed onto new CP plates containing $500 \mathrm{mg} / \mathrm{L}$ cefotaxime (Brithol Michcoma, Holland) and 100 $\mathrm{mg} / \mathrm{L}$ kanamycin. Survival callus were subsequently transferred to the selective IRM after 3 weeks. Putative transgenic shoots regenerated on RM selective medium. Shoots with $2-3 \mathrm{~cm}$ in length were rooted on MS selective medium.

\subsection{Detection of Transformed Plants by PCR Analysis}

Genomic DNA from putative transformants was isolated according to protocol [29]. Rapid detection of transformants was done by PCR analysis. Primer pairs for amplification are forward primer Cry8F (5'CTATTTACAATAAACAATGGCGGGA -3') and reverse primer Cry8R (5' AGATGCGTCTCTAAGCAAAAGGAG -3'). PCR reaction was performed in $20 \mu \mathrm{L}$ volume containing $0.5-1 \mu \mathrm{g}$ of total plant DNA made as follows: $2 \mu \mathrm{L}$ of $10 \mathrm{X}$ Buffer; $0.5 \mu \mathrm{L}$ from each $10 \mu \mathrm{M}$ primer solutions, $0.4 \mu \mathrm{L}$ of $10 \mathrm{mM}$ dNTP; $0.1 \mu \mathrm{L}$ of Taq polymerase (1 unit; ThermoScientific), and adjusted to $20 \mu \mathrm{L}$ with distilled water. The PCR amplification cycles were as follows: $94{ }^{\circ} \mathrm{C}$ for $30 \mathrm{~s}, 58{ }^{\circ} \mathrm{C}$ for $30 \mathrm{~s}$, and $72{ }^{\circ} \mathrm{C}$ for $1 \mathrm{~min}$. This cycle was repeated 35 times and ended up with an elongation step at $72{ }^{\circ} \mathrm{C}$ for $10 \mathrm{~min}$. Visualization of PCR products of $700 \mathrm{bp}$ were done on standard 1\% agarose gel electrophoresis using $20 \mu \mathrm{L}$ of the PCR reaction.

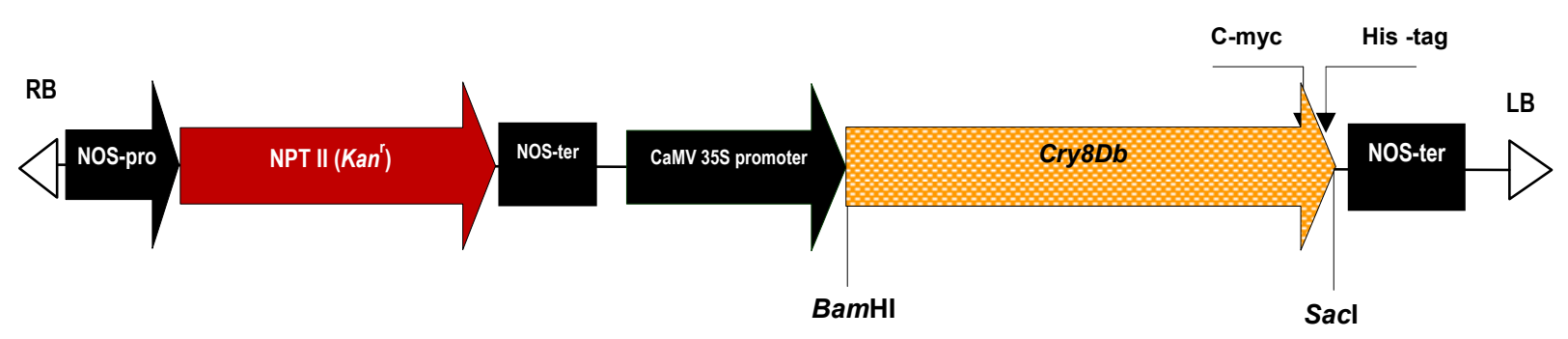

Fig. 1 NptII-Cry8Db cassettes of pBI121 binary vector. 


\subsection{Transgene Insertion Analyzed by Southern Blot} Hybridization

About $40 \mu \mathrm{g}$ of total DNA from transgenic plants were digested with BamHI (40 units) overnight at $37{ }^{\circ} \mathrm{C}$. DNA fragments was electrophoresed in a $1.0 \%$ agarose gel and transferred onto nylon membrane Hybond- $\mathrm{N}^{+}$by alkaline transfer method. The probe was developed by PCR amplification of a fragment of the $C r y 8 D b$ gene. This DNA was used as the probe in the Southern hybridization and was labeled with BIOTIN-11-dUTP. The blots were hybridized at $42^{\circ} \mathrm{C}$ and washed at high stringency $(0.1 \times \mathrm{SSC}, 0.1 \% \mathrm{SDS}$ at $\left.65{ }^{\circ} \mathrm{C}\right)$. Finally, blot was detected by Biotin Chromogenic Detection Kit (Thermo scientific).

\subsection{Biological Tests}

Four transformants exerting Cry $8 D b$-positive PCR and Southern blot were selected to test for weevil resistance. These plantlets were grown in pots and tubers from each transformants separately and harvested after 4 months of planting. The plastic box containing 1-2 pre-weight sweet potato tubers were used to evaluate damage by sweet potato weevil test. Approximately 10 adults per $50 \mathrm{~g}$ sweet potato tubers were released into each box, and the boxes were covered with cloth and kept in dark incubator at $28{ }^{\circ} \mathrm{C}$. After about 35-40 days, the sweet potatoes tubers were cut, and the degree of damage caused by sweet potato weevil wad observed. Damage was evaluated following Moran's method (Fig. 2), considering the parameters: infestation percent (I), and PDI (pondered degree of infestation) [18].

\section{Results and Discussion}

\subsection{Transformation of Cry8db into Sweet Potato via Agrobacterium tumefaciens}

Genetic transformation of plants relies on two independent but concurrent processes: integration of foreign DNA into plant cells and regeneration of whole plants from these transformed cells. In previous experiments the regeneration and transformation protocol of sweet potato via $A$. tumefaciens infection has been demonstrated. $\mathrm{Vu}$ and colleagues established an efficient regeneration system for KB1 sweet potato variety with highest shoot regeneration efficiency $(67.75 \%)$ [26, 27]. Furthermore, study on factors affecting agrobacterium-mediated transformation of KB1 sweet potato variety suggested that shoot tip or apical explants infected with Agrobacterium tumefaciens strain $\mathrm{C} 58$ at the concentration of $\mathrm{OD}_{600 \mathrm{~nm}}$ $0.8,150 \mu \mathrm{M}$ acetosyringone supplied in bacterial suspension solution and 20-30 min infection time gave the highest percentage of GUS positive transformants $(38 \%)$ [26, 27]. In the present study, genetic transformation of sweet potato via $A$. tumefaciens harboring the binary vector construct $\mathrm{pBI} 121 /$ cry $8 \mathrm{Db}$ comprising the DNA coding insecticidal crystal protein $C r y 8 D b$ has been carried out (Fig. 1).

Approximately 1000 pre-culture explants per experiment were infected with $A$. tumefaciens $\mathrm{C} 58 \mathrm{cv}$ harboring $\mathrm{pBI} 121 /$ cry $8 D b$. After transformation, these explants were cultured into the selective medium

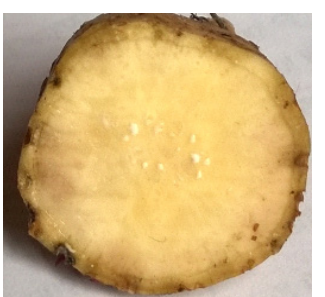

Control

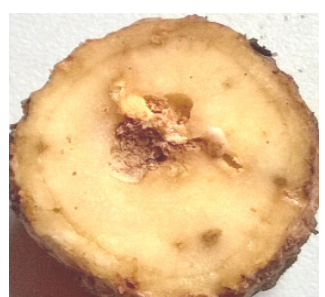

Value 1

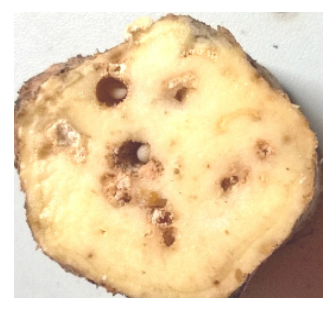

Value 2

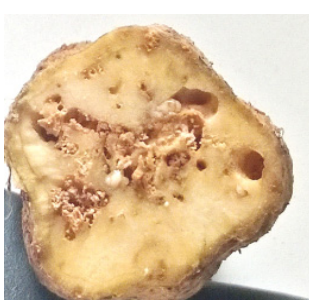

Value 3

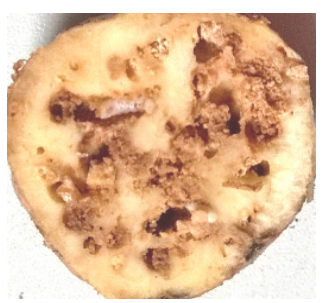

Value 4

Fig. 2 Evaluation of transgenic sweet potato tubers for resistance to sweet potato weevil (C. formicarius) under controlled conditions.

Values of scale of damages (from 1 to 4 ) deal with the percent of the tuber that is damaged. 
Table 1 Agrobaterium-mediated transformation efficiency of cry8Db gene into KB1 sweet potato cultivar.

\begin{tabular}{|c|c|c|c|c|c|c|c|c|c|}
\hline \multirow{2}{*}{$\begin{array}{l}\text { Transformation } \\
\text { No. }\end{array}$} & \multirow{2}{*}{$\begin{array}{l}\text { Explants } \\
\text { infected }\end{array}$} & \multicolumn{3}{|c|}{$\begin{array}{l}\text { No. of survival calli on } \\
\text { selection medium }\end{array}$} & \multirow{2}{*}{$\begin{array}{l}\text { No. } \\
\text { regenerated } \\
\text { calli }\end{array}$} & \multirow{2}{*}{$\begin{array}{l}\text { No. regenerated } \\
\text { shoots }\end{array}$} & \multirow{2}{*}{$\begin{array}{l}\text { No. } \\
\text { rooted } \\
\text { shoots }\end{array}$} & \multirow{2}{*}{$\begin{array}{l}\text { PCR } \\
(\%)\end{array}$} & \multirow{2}{*}{$\begin{array}{c}\text { positive Transformation } \\
\text { efficiency }(\%)\end{array}$} \\
\hline & & $\overline{\mathrm{CP}}$ & IRM & $\mathrm{RM}$ & & & & & \\
\hline 1 & 893 & 595 & 262 & 45 & 12 & 42 & 19 & 2 & \\
\hline 2 & 1,210 & 785 & 355 & 53 & 10 & 57 & 21 & 2 & \\
\hline 3 & 1,020 & 680 & 300 & 50 & 13 & 44 & 16 & 2 & \\
\hline 4 & 780 & 666 & 352 & 63 & 15 & 57 & 12 & 2 & \\
\hline 5 & 1,130 & 753 & 332 & 59 & 20 & 51 & 23 & 3 & \\
\hline 6 & 800 & 533 & 533 & 42 & 6 & 38 & 20 & 1 & \\
\hline 7 & 1,150 & 338 & 172 & 50 & 9 & 55 & 25 & 3 & \\
\hline 8 & 1,120 & 880 & 382 & 56 & 15 & 52 & 23 & 2 & \\
\hline 9 & 1,012 & 674 & 297 & 53 & 17 & 48 & 22 & 2 & \\
\hline 10 & 1,048 & 698 & 308 & 65 & 29 & 55 & 20 & 2 & \\
\hline Sum & 10,163 & 6,602 & 3,293 & 536 & 146 & 499 & 201 & 21 & 0.21 \\
\hline $\mathrm{Wt}$ & 100 & 100 & 32 & 0 & 0 & 0 & 0 & 0 & 0 \\
\hline
\end{tabular}

Wt: untransformed experiment; CP: callus production medium; IRM: induction regeneration medium; RM: regeneration medium.

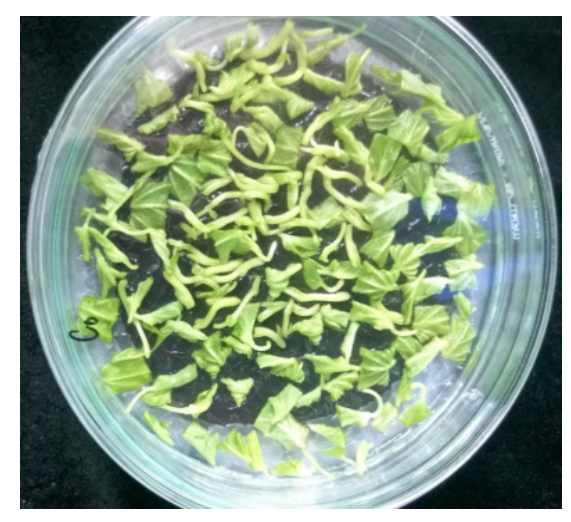

(a)

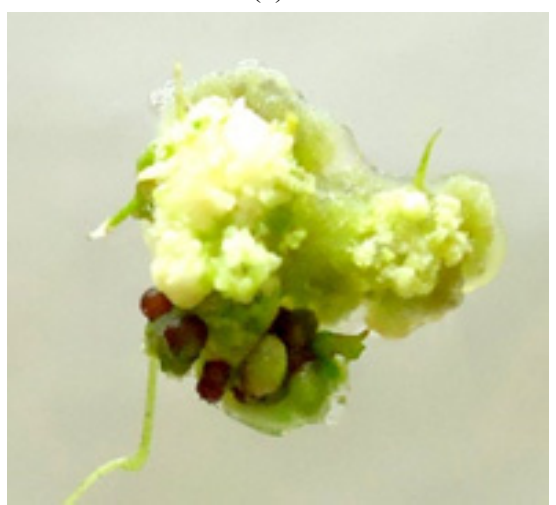

(d)

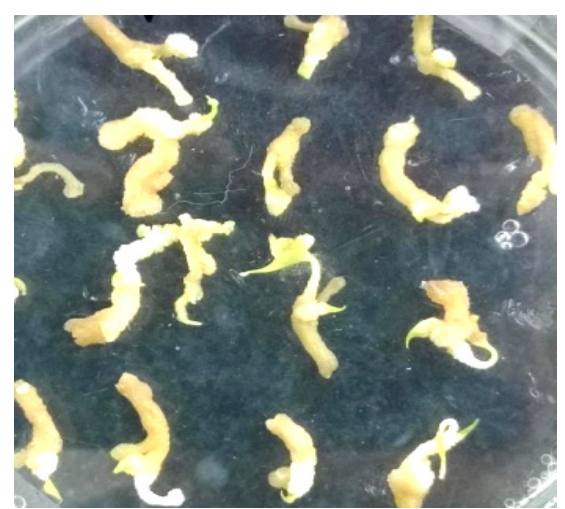

(b)

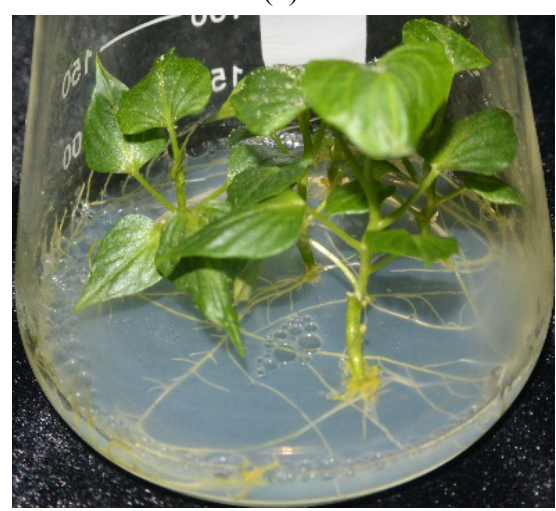

(e)

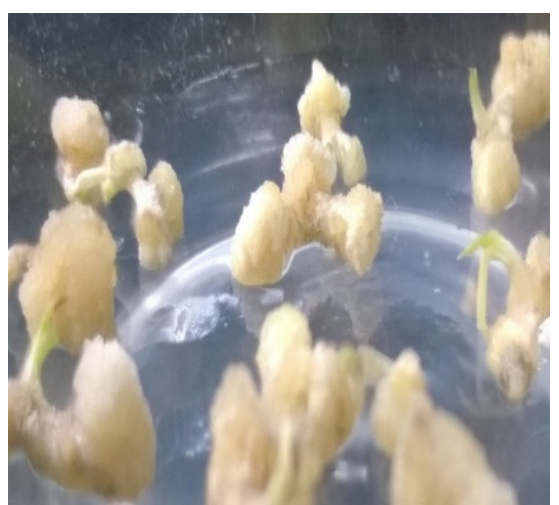

(c)

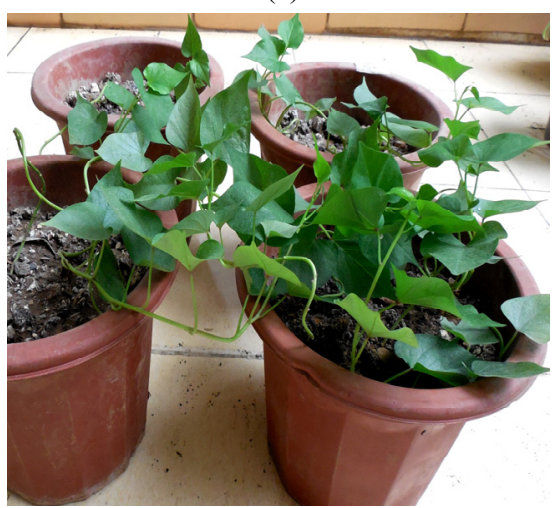

(f)

Fig. 3 Transformation and regeneration sweetpotato KB1 plants.

(a) Explants infected with A. tumefaciens $C 58$ on co-cultivation medium for 2 days; (b) Callus induction from explants in selective medium; (c) Transgenic callus formation from shoot tip segments after 3-4 weeks in selective medium; (d) Shoot regeneration from survival embrygenic callus after 4 weeks on regeneration medium; (e) Transgenic plants in rooted medium; (f) Morphological characterization of transgenic lines in soil pots in the greenhouse. 
according to two stage regeneration protocol. Shoots usually developed after 7-8 weeks from the wounded on the selective regeneration medium (Fig. 3). In present study, ten sets of transformation experiments were carried out with about 10,163 explants in total. After three weeks in CP selective medium, about 6,602 putative transformed calluses (65\%) were obtained based on antibiotic resistance selection. These survival calluses were transferred continuously into the IRM and then RM selective medium. After three to five weeks under kanamycin selective pressure, 146 embryogenesis calluses produced 499 shoots (Table 1). These regenerated shoots with 2-3 $\mathrm{cm}$ in length were rooted on MS selective medium. From these shoots, 201 rooted plantlets were chosen for PCR and further analyses. Under kanamycin pressure, almost all of these shoots grew slowly and there are two kinds of root emergence from shoots. The thin and weak roots arising from above stem and the healthy and long roots arising from the end of cutting stem were observed (Fig. 3).

\subsection{Molecular Analysis of Transgenic Plants}

In order to confirm the presence of the cry $8 \mathrm{Db}$ gene, the gel electrophoresis of PCR products from the putative transformants and the wild type as well as $A$. tumefaciens using Cry $8 D b$-specific primer pairs showed that $c r y 8 \mathrm{Db}$ fragment was present in 21 transgenic clones but not in the wild type (Fig. 3) whereas the virC PCR product was absent (Data not shown). These results proved that the transgenic plants were actually transformed with $C r y 8 D b$ and were not contaminated with Agrobacterium [30]. This result also showed that the use of high concentration of kanamycin at $100 \mathrm{mg} / \mathrm{L}$ for selection of putative transformed clones still gave ambiguous results. Most of the root formation of 21 positive PCR plantlets arising from the bottom of the cutting stem was observed.

The copy number of integrated DNA was analyzed by Southern blot. DNA of transgenic plants was digested with $B a m \mathrm{HI}$, at the BamHI unique cleavage site in the T-DNA region in the vector. The fragments were hybridized with the $c r y 8 D b$ gene probe (Fig. 4). These transgenic plants showed different patterns, and the number of integrated copies varied from 1 to 4 . Four transgenic plants carrying a single copy of the $c r y 8 D b$ gene were used for biotest.

\subsection{Biological Test Results}

Four transgenic sweet potato plants proved positively in Southern hybridization with a single copy of the
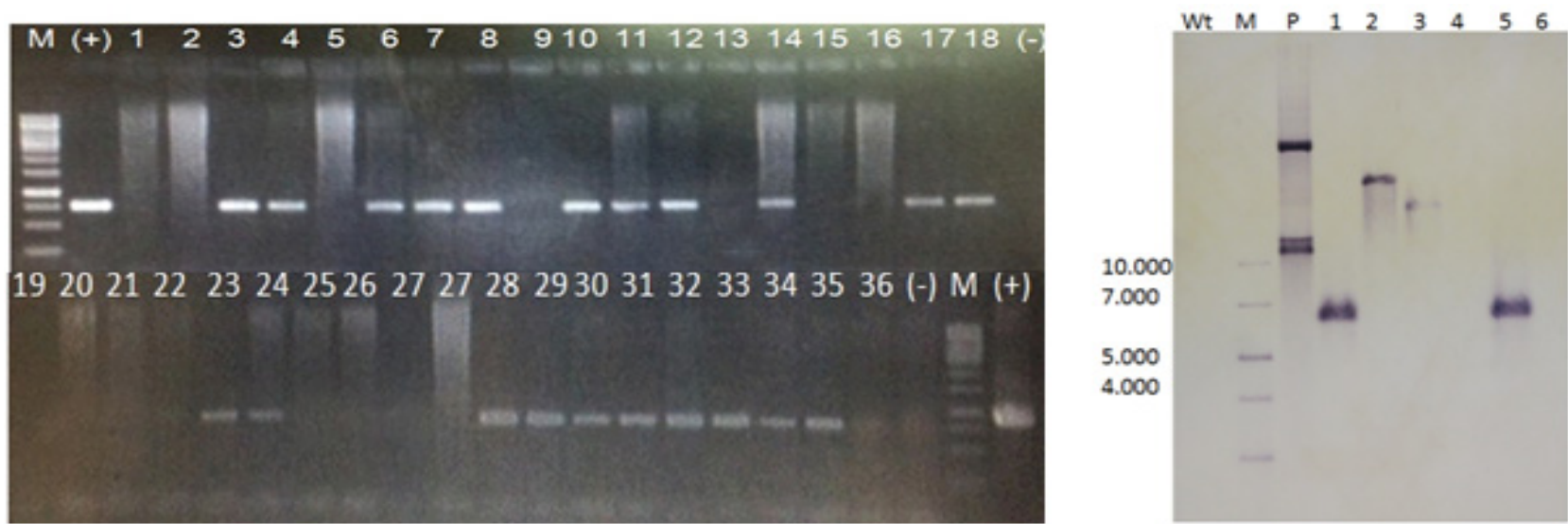

Fig. 4 Confirmation of $c r y 8 D b$ gene integration into the sweet potato genome by PCR (A) and Southern blot analysis (B). A: (M) Molecular marker $1 \mathrm{~kb}$ (Fermentas); (+): positive control, plasmid DNA; (-): negative control, untransformed plant genomic DNA; Lane 1-36: putative transgenic sweetpotato lines;

B: 30-50 $\mu \mathrm{g}$ of total DNA from leaves of the transgenic clones and from the untransformed control were independently digested with BamHI; P: undigested plasmid DNA; Wt: untransformed plant genomic DNA; Lane1-6: genomic DNA of putative transgenic sweetpotato lines; M: Molecular marker. 
cry $8 \mathrm{Db}$ gene and the wild type were grown in pots in greenhouse and the roots were harvested after 4-5 months of planting. The size of sweet potato roots harvested in our study ranging from $70 \mathrm{~g}$ to $125 \mathrm{~g}$ (Data not shown). This could be due to the limited of the growing pots and farming methods. Damage was evaluated following Moran's method [18]. Scale of damages (ranging from 1 to 4 ) has been represented in Fig. 4. According to parameters including infestation percentage and pondered degree of infestation, biotests against sweet potato weevil of these transgenic lines showed that the level of infestation by weevils in untransformed control plants was higher than that of transgenic lines (Table 2). In the experiment, the pondered degree of infestation of transgenic lines was from 1.33 to 1.75 lower than untransformed plants (2.3).

The sweet potato weevil is the major sweet potato insect pest worldwide, however, only three reports on transformed plants with insecticidal genes cowpea trypsin inhibitor, snowdrop lectin genes and cryIII gene have been published thus far [17, 18, 31]. Also, it is known that $\mathrm{Bt}$ is widely used in pest control agents, especially highly activate against lepidopteran pests. A few insecticidal proteins from Bt strains that are toxic for coleopteran insects such as Cry8, Cry3, Cry 7 have been reported [24, 32, 33]. These findings are in good agreement with the authors' previous studies that the activity of $c r y 8 D b$ gene in E.coli against sweetpotato weevil (Cylas formicarius) were confirmed (experimental unpublished data). In present study, for the first time, the novel of $c r y 8 D b$ gene from Bt (Bacillus thuringiensis) proved to be toxic to sweet potato weevil and was successfully used to transform into KB1 sweet potato variety.

From 201 putative transgenic shoots regenerated, 21 transgenic plants have been confirmed successfully by PCR and Southern blot. This result is in agreement with Luo's study [34] which showed that the untransformed escapes of all regeneration plantlets were observed. In the authors' experiments, the obtained transformation frequencies of about $0.21 \%$ indicates the difficulty of Agrobacterium mediated transformation of insecticidal genes into sweet potato. This result is also associated with our previous studies where insecticidal genes cry3cal and vip1-2 were used (experimental data unpublished) and other reports [17, 18]. To date, several reports on the Agrobacterium-mediated transformation of sweet potato have been published. However majority of the most efficient and robust Agrobacterium transformation systems succeed in transformation of marker genes such as gfp, gus A, nptII, bar [5, 10, 34-37]. Therefore, genetic transformation of sweet potato remains cumbersome and labor-intensive due to the difficulty in plant regeneration of several recalcitrant cultivars, and the reproducibility of the used protocol [15, 17, 34, 36-39].

Four of transformants carrying a single copy of $C r y 8 D b$ have been tested for biological activity against sweet potato weevil. Under the control conditions, levels of infestation by weevils in untransformed control plants were $58.3 \%$ and almost 1.7 times higher in comparison to the best transgenic clones (Table 2).

Table 2 Evaluation of transgenic sweet potato clones for resistance to sweet potato weevil (C. formicarius) under controlled conditions.

\begin{tabular}{lll}
\hline Clone & I & PDI \\
\hline Wt & 58.3 & 2.3 \\
C8 (8.1) & 37.5 & 1.5 \\
C8 (8.2) & 43.75 & 1.75 \\
C8 (8.3) & 40.0 & 1.6 \\
C8 (8.4) & 33.33 & 1.33 \\
\hline C8 (8.1-8.4): Four tranger
\end{tabular}

C8 (8.1-8.4 ): Four transgenic lines confirmed by PCR reaction and Southern blot; Wt: Untransformed plants; I: Infestation percent; PDI: Pondered degree of infestation. 
For that reason, these transgenic plants were selected to be tested for $\mathrm{cMyc}$ using Western blot. Unfortunately, bands of transgenic clones were practically undetectable despite correct technical performance (detectable $25 \mathrm{ng}$ positive SCFv_cmyc) (Data not shown). This result is coincident with a previous report which proposed that the CryIIIA toxin band in sweet potato transgenic plant is undetectably but the biological result still showed resistance against sweet potato weevil [18].

\section{Conclusion}

In conclusion, the sweet potato genetic transformation via Agrobacterium was performed successfully in our laboratory. With the importance of the sweet potato KB1 cultivar in Vietnam, the successful transformation of $C r y 8 D b$ into KB1 cultivar and generation of weevil-resistant transgenic plants will contribute to increasing the yield and food security in Vietnam in the near future.

\section{Acknowledgement}

The present study was financially supported by Key Program for Development and Application of Biotechnology in Agriculture sector and Rural development to 2020, MARD with the project title "Study on generating transgenic sweet potatoes for resistance against sweet potato weevil".

\section{References}

[1] Pua, E., and Davey, M. 2007. Transgenic Crops IV: Biotechnology in Agriculture and Forestry. BerlinHeidelberg: Springer-Verlag.

[2] Food and Agriculture Organization of the United Nations, FAOSTAT database (FAOSTAT, 2014), Accessed May 16, 2014. http://faostat.fao.org.

[3] Dhir, S. K., Oglesby, J., and Bhagsari, A. S. 1998. "Plant Regeneration via Embryogenesis, and Transient Gene Expression in Sweet Potato Protoplasts." Plant Cell Reports 17: 665-9.

[4] Mitchell, T. D., Bhagsari, A. S., Ozias-Akins, P., and Dhir, S. K. 1998. "Electro Poration-Mediated Transient Gene Expression in Intact Cells of Sweet Potato." In
Vitro Plant 34 (4): 319-24.

[5] Lawton, R., Winfield, S., Daniell, H., Bhagsagi, A. S., and Dhir, S. K. 2000. "Expression of Green-Fluorescent Protein Gene in Sweet Potato Tissues." Plant Molecular Biology Reports 18: 139a-139i.

[6] Prakash, C. S., and Varadarajan, U. 1992. "Genetic Transformation of Sweet Potato by Particle Bombardment." Plant Cell Reports 11: 53-7.

[7] Murata, T., Okada, Y., Saito, A., Kimura, T., Mori, M., and Nishiguchi, M. et al. 1998. "Transformation by Direct Gene Transfer in Sweet Potato (Ipomoea batatas (L.) Lam.)." In Proceedings of International Workshop. Sweet Potato Production System toward the 21st Century, Japan, Kyushu National Agricultural Station.

[8] Okada, Y., Saito, A., Nishiguchi, M., Kimura, T., Mori, M., and Hanada K. et al. 2001. "Virus Resistance in Transgenic Sweet Potato [Ipomoea batatas (L.) Lam] Expressing the Coat Protein Gene of Sweet Potato Fearther Mottle Virus." Theoretical and Applied Genetics 103: 743-51.

[9] Okada, Y., Saito, A., Nishiguchi, M., Kimura, T., Mori, M., and Matsuda, Y. et al. 2002. "Microprojectile Bombardment-Mediated Transformation of Sweet Potato (Ipomoea batatas (L.) Lam.)." SABRAO Journal of Breeding and Genetics 34 (1): 1-8.

[10] Yi, G., Shin, Y. M., Choe, G., Shin, B., Kim, Y. S., and Kim, K. M. 2007. "Production of Herbicideresistant Sweet Potato Plants Transformed with the Bar Gene." Biotechnology Letters 29: 669-75.

[11] Okada, Y., and Saito, A. 2009. "Evaluation of Resistance to Complex Infection of SPFMVs in Transgenic Sweet Potato (Ipomoea batatas)." Breed Science (Jpn) 58 (3): 243-50.

[12] Otani, M., Mii, M., Handa, T., Kamada, H., and Shimada, T. 1993. "Transformation of Sweet Potato (Ipomoea batatas (L.) Lam.) Plants by Agrobacterium rhizogenes." Plant Science 94: 151-9.

[13] Hansen, G., Shillito, R. D., and Chilton, M. D. 1997. "T-strand Integration in Maize Protoplasts after Codelivery of a T-DNA Substrate and Virulence Genes." Proc Natl Acad Sci USA 94: 11726-30.

[14] Otani, M., Wakita, Y., and Shimada, T. 2003. "Production of Herbicide-Resistant Sweet Potato (Ipomoea batatas (L.) Lam.) Plants by Agrobacterium tumefaciens Mediated Transformation.” Breed Science 53: 145-8.

[15] Anwar, N., Junko, K., and Watarabe, A. 2011. "Transgenic Sweet Potato Expressing Mammalian Cytochrome P450." Plant Cell Tissue and Organ Culture 105: 219-31. 
[16] Sivparsad, B. J., and Gubba, A. 2014. "Development of Transgenic Sweet Potato with Multiple Virus Resistance in South Africa." Transgenic Research 23 (2): 377-88.

[17] Newell, C. A., Lowe, J. M., Merryweather, A., Rooke, L. M., Hamilton, W. D. O. 1995. "Transformation of Sweet Potato (Ipomoea batatas (L.) Lam.) with Agrobacterium tumefaciens and Regeneration of Plants Expressing Cowpea Trypsin Inhibitor and Snowdrop Lectin." Plant Science 107 (2): 215-27.

[18] Kimura, T., Otani, M., Noda, T., Ideta, O., Shimada, T., and Saito, A. 2001. "Absence of Amylose in Sweet Potato (Ipomoea batatas (L.) Lam) Following the Introduction of Granule-Bound Starch Synthase cDNA." Plant Cell Reports 20: 663-6.

[19] Shimada, T., Otani, M., Hamada, T., and Kim, S. H. 2006. "Increase of Amylose Content of Sweet Potato Starch by RNA Interference of the Starch Branching Enzyme II Gene (IbSBEII)." Plant Biotechnology 23: 85-90.

[20] Asano, S., Yamashita, C., Iizuka, T., Takeuchi, K., Yamanaka, S., and Cerf, D. et al. 2003. "A Strain of Bacillus thuringiensis Subsp Galleriae Containing a Novel cry8 Gene Highly Toxic to Anomala Cuprea (Coleoptera: Scarabaeidae)." Biological Control 28 (2): 191-6.

[21] Hong, Y., Zhang, J., Huang, D., Gao, J., and Song, F. 2006. "Characterization of Bacillus thuringiensis Strain Bt185 Toxic to the Asian Cockchafer." Holotrichia parallela, Current Microbiology 53: 13-7.

[22] Sato, R., Takeuchi, K., Ogiwara, K., Minami, M., Kaji, Y., and Suzuki, N. et al. 1994. "Cloning, Heterologous Expression, and Localization of a Novel Crystal Protein Gene from Bacillus thuringiensis Serovar Japonensis Strain Buibui Toxic to Scarabaeid Insects." Current Microbiology 28 (1): 15-9.

[23] Yamaguchi, T., Sahara, K., Bando, H., and Asano, S. 2008. "Discovery of a Novel Bacillus thuringiensis Cry $8 D$ Protein and the Unique Toxicity of the Cry $8 D$-Class Proteins Against Scarab Beetles." Journal Invertebr Pathol 99 (3): 257-62.

[24] Chee, R. P., Leskovar, D. I., and Cantliffe, D. J. 1992. "Optimizing Embryogenic Callus, Embryo Growth of a Synthetic Seed System for Sweet Potato by Varying Media Nutrient Concentration." Journal of the American Society for Horticultural Science 117: 663-7.

[25] Vu, T. L., Mai, T. P. N., Nguyen, T. N., Le, T. N., Pham, B. N. and Chu, H. H. et al. 2013b. "Research on Factors Affecting Agrobacterium-Mediated Transformation of Sweet Potato. Vietnam National Biotechnology conference_Hanoi." Natural Sciences and Technology (2013b): 888-92.
[26] Vu, T. L., Nguyen, T. N., Nguyen, D. T., Pham, B. N., Chu, H. H., and Le, T. B. 2013a. "The Efficiency of ABA and GA3 on Process of Multiple Shoot Induction from Callus of Sweet Potato (Ipomoea batatas (L.) Lam)." Jounal of Biotechnology 11 (4): 727-34.

[27] Murashige, T., and Skoog, F. 1962. "A Revised Medium for Rapid Growth and Bioassays with Tobacco Tissue Cultures." Physiology Plant 15 (3): 473-97.

[28] Khanuja, S. P. S., Shasany, A. K., Darokar, M. P., and Kumar, S. 1999. "Rapid Isolation of DNA from Dry and Fresh Samples of Plants Producing Large Amounts of Secondary Metabolites and Essential Oils." Plant Mol Biol Rep. 17: 1-7.

[29] Zayed, R., and Wink, M. 2004. "Induction of tropane alkaloid formation in transformed root cultures of Brugmansia suaveolens (Solanaceae)." Z. Naturforsch C. 59: 863-7.

[30] García, R., Morán, R., Mena, J., Somontes, D., Pimentel, E., and Zaldúa, Z. et al. 2000. "Sweet Potato (Ipomoea batatas L.) Regeneration and Transformation Technology to Provide Weevil (Cylas formicarius) Resistance. Field Trial Results." Developments in Plant Genetics and Breeding 5: 112-7.

[31] Ekobu, M., Solera, M., Kyamanywa, S., Mwanga, R. O., Odongo, B., and Ghislain, M. et al. 2010. "Toxicity of Seven Bacillus thuringiensis Cry Proteins Against Cylas Puncticollis and Cylas Brunneus (Coleoptera: Brentidae) Using a Novel Artificial Diet." Journal of Economic Entomology 103 (4): 1493-502.

[32] Yamaguchi, T., Sahara, K., Bando, H., and Asano, S. 2010. "Intramolecular Proteolytic Nicking and Binding of Bacillus thuringiensis Cry8Da Toxin in BBMVs of Japanese Beetle." Journal Invertebr Pathol 105 (3): 243-7.

[33] Luo, H. R., Sata Maria, M., Benavides, J., Zhang, D. P., Zhang, Y. Z. and Ghislain, M. 2006. "Rapid Genetic Transformation of Sweet Potato (Ipomoea batatas (L.) Lam) via Organogenesis." African Journal of Biotechnology 5 (20): 1851-7.

[34] Yu, B., Zhai, H., Wang, Y., Zang, N., Wang, Y., and Liu, Q. 2007. "Efficient Agrobacterium tumefaciens-Mediated Transformation Using Embryogenic Suspension Cultures in Sweet Potato, Ipomoea batatas (L.) Lam." Plant Cell Tiss Organ Cult 90: 265-73.

[35] González, R. G., Sánchez, D. S., Guerra, Z. Z., Campos, J. M., Quesada, A. L. and Valdivia, R. M. et al. 2008. "Efficient Regeneration and Agrobacterium tumefaciens Mediated Transformation of Recalcitrant Sweet Potato (Ipomoea batatas L.) Cultivars." Asia Pacific Journal of Molecular Biology and Biotechnology 16 (2): 25-33. 
[36] Xing, Y.J., Ji, Q., Yang, Q., Luo, Y.-M., Li, Q. and Wang, X. 2008. "Studies on Agrobacterium Mediated Genetic Transformation of Embryogenic Suspension Cultures of Sweet Potato." African Journal of Biotechnology 7 (5): 534-40.

[37] Otani, M., Shimada, T., Kimura, T. and Saito, A. 1998. "Transgenic Plant Production from Embryogenic Callus of Sweet Potato (Ipomoea batatas (L.) Lam.) Using Agrobacterium tumefaciens." Plant Biotechnol 15: 11-6.

[38] Berberich, T., Takagi, T., Miyazaki, A., Otani, M., Shimada, T. and Kusano, T. 2005. "Production of Mouse Adiponectin, an Antidiabetic Protein, in Transgenic Sweet Potato Plants.” Journal Plant Physiology 162 (10): 1169-76. 